\title{
Is innovation always beneficial? A meta-analysis of the relationship between innovation and performance in SMEs
}

\author{
Nina Rosenbusch ${ }^{\mathrm{a}, *}$, Jan Brinckmann ${ }^{\mathrm{b}, 1}$, Andreas Bausch ${ }^{\mathrm{a}, 2}$ \\ ${ }^{a}$ Friedrich-Schiller-University Jena, Faculty of Economics and Business Administration, Carl-Zeiss-Str. 3, 07743 Jena, Germany \\ b ESADE, Av. Pedralbes, 60-62, E-08034 Barcelona, Spain
}

\section{A R T I C L E I N F O}

\section{Article history:}

Received 12 June 2009

Received in revised form 14 December 2009

Accepted 15 December 2009

Available online 21 January 2010

\section{Keywords:}

Innovation

Firm performance

SME

New ventures

Meta-analysis

\begin{abstract}
A B S T R A C T
The performance implications of innovation in small and medium-sized enterprises (SMEs) have attracted considerable interest among academics and practitioners. However, empirical research on the innovation-performance relationship in SMEs shows controversial results. This meta-analysis synthesizes empirical findings in order to obtain evidence whether and especially under which circumstances smaller, resource-scarce firms benefit from innovation. We find that innovation-performance relationship is context dependent. Factors such as the age of the firm, the type of innovation, and the cultural context affect the impact of innovation on firm performance to a large extent.
\end{abstract}

(c) 2009 Elsevier Inc. All rights reserved.

\section{Executive summary}

In search for constitutive elements of entrepreneurship, various prominent scholars argue that innovation is the key distinguishing attribute vis-à-vis business administration and other disciplines (e.g., Schumpeter, 1982; Davidsson, 2004). Moreover, substantial practitioner-oriented literature suggests that in order to survive and thrive in increasingly hypercompetitive markets, innovation is the only solution (e.g., Kim and Maubourgne, 2005). Not surprisingly, the quest for the big idea that promises entrepreneurial success is characterized by the identification of a radically innovative offering, production process, and/or business model. This venturing approach reflects the widespread assumption that in order to be successful, the entrepreneur or small business manager needs to have an innovative edge to compete against bigger, well-established incumbents. Yet, does empirical evidence support this assumption? Is innovation indeed always the better approach? What are contextual factors that might impact the innovation-performance relationship?

In this study, we apply meta-analyses techniques to aggregate prior empirical research on the innovation-performance relationship. In so doing, we are able to determine the direction and effect-strength innovation has on the performance of small and medium-sized firms (SMEs). Furthermore, the meta-analysis approach allows us to present evidence whether moderators impact the innovation performance relationship. Our analysis aggregates 42 empirical studies on 21,270 firms.

Our findings show that innovation has a positive effect on the performance of SMEs. Yet, we also identify a number of factors that impact the innovation-performance relationship: first, fostering an innovation orientation has more positive effects on firm performance than creating innovation process outcomes such as patents or innovative products or services. This result highlights that entrepreneurs and SME managers focusing only on creating innovative offerings miss important dimensions which are essential for

\footnotetext{
* Corresponding author. Tel.: +49 3641 943164; fax: +49 3641943162.

E-mail addresses: nina.rosenbusch@wiwi.uni-jena.de (N. Rosenbusch), jan.brinckmann@esade.edu (J. Brinckmann), andreas.bausch@wiwi.uni-jena.de (A. Bausch).

1 Tel.: +349328061 62; fax: +34932048105.

2 Tel.: +49 3641 943161; fax: +493641943162.
} 
realizing the value that innovation can provide to their firms. Second, when comparing the performance implications of dedicating more resources to innovation process inputs (e.g., R\&D spending) with innovation process outcomes, we find that the innovation process outcomes lead to a greater increase in SME performance. This finding underlines the importance for entrepreneurs and SMEs to manage the innovation process diligently. Being aware of the importance of innovation and subsequently dedicated substantial resources to the innovation task might not be sufficient, as the expected performance implication might not substantiate. Third, innovation has a stronger impact in younger firms than in more established SMEs. This finding suggests that the often cited liability of newness of younger firms can also be an asset for new firms. Our finding indicates that new firms possess unique capabilities to create and appropriate value through innovations. Fourth, we find that internal innovation projects increase the performance substantially while innovation projects that involve external collaborations have no significant effect on performance. Hence, empirical evidence provided in this study challenges network and social capital literature which suggests that more collaboration with external partners is better for the new and small firm; especially in the context of innovation this might not be the case. Fifth, our findings illustrate that the cultural context in which the firms operate impacts the innovation-performance relationship. Yet, the identified relationship contradicts popular assumptions. We find that innovation has the strongest positive impact in cultural environments characterized by collectivism such as those found in many Asian countries. In contrast, in more individualistic cultures such as the U.S., the relationship between innovation and performance is weaker. We interpret the different findings and discuss implications for academia and practitioners and also identify gaps that can be addressed in future research.

\section{Introduction}

When nascent entrepreneurs pitch their business ideas, one argument is predominantly employed: nobody else is doing what we are about to do. This argument reflects a deeply engrained belief that in order to be successful in business, the entrepreneur or small business manager needs to have an innovative edge to compete against bigger incumbents. Prominent entrepreneurship scholars support this notion by arguing that innovation is a constitutive element of entrepreneurship (e.g., Schumpeter, 1982; Davidsson, 2004; Lumpkin and Dess, 1996). In addition, some strategy literature proposes that smaller organizations can profit by adjusting to environmental changes faster than bigger organization due to their nimbleness, missing hierarchies, and quick decision-making (Nooteboom, 1994; Vossen, 1998). Moreover, the general public attributes greater promise to smaller firms investing heavily in innovations than larger organizations (Lee and Chen, 2009). In consequence, an entrepreneur or small business manager is likely to conclude that innovation benefits new and small firm development irrespective of the circumstances. Yet, does theory and empirical evidence support the general assumption that innovation is indeed always the better approach?

In contrast to literature proclaiming the positive aspects of innovation which frequently focuses on large firms, substantial theory challenges this view. Van de Ven (1986) cautions that innovation demands substantial resources. For resource-scarce small firms, the resources required by innovation projects can overstrain their possibilities (Acs and Audretsch, 1988; Nooteboom, 1994; Vossen, 1998). Additionally, innovation implies increased uncertainty and risks (Eisenhardt and Martin, 2000; Knight, 1921). While larger organizations have the resource slack to absorb failure, for smaller entities the failure of an innovative product evokes existential risks (Nohria and Gulati, 1996). Furthermore, big organizations are more likely to have experience with innovation projects leading to organizational innovation capabilities (Majchrzak et al., 2004; Danneels, 2002; Galunic and Rodan, 1998). Smaller and especially new firms often lack this organizational capability and, thus, experience running the risk of engaging in managerial undertakings without experience. Reflecting on the perils of innovation, it needs to be noted that innovation is a task fraught with high failure rates (Crawford, 1987; Berggren and Nacher, 2001) or at least temporary unprofitability (Block and MacMillan, 1993). Additionally, empirical studies investigating the innovation-performance relationship frequently present mixed findings. Various empirical studies report that innovation does not influence firm performance (e.g., Birley and Westhead, 1990; Heunks, 1998) or find negative performance implications of innovation (e.g., McGee et al., 1995; Vermeulen et al., 2005). Meanwhile other research reports positive effects (e.g., DeCarolis and Deeds, 1999; Guo et al., 2005; Li and Atuahene-Gima, 2001, 2002). Reviews of the innovation-performance research describe the evidence as 'mixed', 'inconclusive', 'contradictory' (Li and Atuahene-Gima, 2001: 1123). This literature, however, is based on ad-hoc narrative reviews and generally refers to big, established firms. A systematic analysis of the innovation-performance relationship in SMEs to our best knowledge is nonexistent. This is surprising, as unstructured narrative reviews can include sampling, measurement, stochastic, and external validity problems and generally do not allow the quantification of the relationships (Hunter and Schmidt, 2004). Furthermore, narrative reviews frequently incorporate various cognitive and normative biases of the researcher (Rauch and Frese, 2006). To overcome these limitations, meta-analysis is an established and powerful method to systematically synthesize findings as part of an evidence-based research approach. Evidence-based research aims to substantiate research findings based on an aggregation of empirical findings. Meta-analysis is a quantitative and systematic method developed to integrate past empirical findings (Hunter and Schmidt, 2004). It provides the opportunity to determine the strengths of direct effects and allows the identification of moderating effects. According to Rousseau et al. (2008: 491), "meta-analysis is intended to establish a way to tell what is true, as best we can tell." Recently, meta-regressions have been introduced to entrepreneurship literature as a form to estimate multiple moderation effects based on multivariate analysis (Brinckmann et al., 2010).

Following an evidence-based research approach, this study provides the first quantitative aggregation of empirical findings on the innovation-performance relationship. This is important, as the emerging field of entrepreneurship has to critically examine fundamental pillars it is based on. If innovation does not contribute value for the entrepreneur, questions are raised whether or not it can be a foundation of entrepreneurship theory. Moreover, if innovation only attributes value in some unique entrepreneurial circumstances, it can be questioned whether it should be a component of a general theory of entrepreneurship. 
Beyond scrutinizing the general relationship between innovation and performance, we especially aim to add to literature by providing a more detailed, contextual understanding of the innovation-performance relationship. In other words, we seek to address a second, complementary research question: In which contexts is innovation more beneficial for the performance of the small firm?

Strategy and entrepreneurship researchers have highlighted the importance of contextual factors as contingencies (e.g., Dess et al., 1997; Downs and Mohr, 1976). Initial individual studies also suggest that the innovation-performance relationship is moderated (e.g., Covin and Slevin, 1989; Li and Atuahene-Gima, 2001; Thornhill, 2006). Furthermore, the prima facie conflicting empirical findings additionally indicate the existence of contextual moderators. Various factors can be expected to impact the innovation-performance relationship. Potential moderators include firm and firm-environment specific factors. Fig. 1 depicts the research framework of this meta-analysis. Following prior literature, we define innovation as the process of the adoption of internally or externally generated devices, systems, policies, programs, processes, products, or services that are new to the adopting organization (Damanpour, 1991). We first analyze the direct impact of innovation as an aggregate of the different innovation forms on firm performance. Subsequently, we analyze whether the strength of the innovation-performance relationship depends on the type of innovation activity. Furthermore we study two contextual factors that may influence the innovation-performance relationship: firm age as a condition referring to the firminternal characteristics and national culture as a dimension reflecting firm-external characteristics.

Specifically, we aim to contribute five novel insights to literature: first, we provide an aggregate analysis of empirical studies focusing on the innovation-performance relationship in SMEs. While prior meta-analyses have provided insightful findings with regard to antecedents of innovation (Damanpour, 1991; Tornatzky and Klein, 1982; Camison-Zornosa et al., 2004), a quantitative empirical aggregation of prior empirical evidence regarding consequences of innovation in SMEs has not been undertaken. Second, we analyze whether the type of innovation moderates the innovation-performance relationship. Our analysis distinguishes different types of innovation as antecedents of firm performance: 1) innovation orientation of the venture, 2) inputs dedicated to an innovation process (e.g. R\&D and innovation expenditures, R\&D employees, number of R\&D alliances), and 3) outputs derived from an innovation process (e.g., the number of patents and new products, the share of sales derived from new products). Thus, we examine whether an innovation orientation, innovation process inputs, or a focus on innovation process outputs lead to diverging performance effects (e.g., Roberts, 1990; Wolff, 2007). This analysis contributes to our understanding of how to manage innovation in SMEs. Third, we more specifically investigate whether entrepreneurs or small business managers should focus on internally generated innovation by relying on own innovation resources or if it is more effective to focus on the development of innovation through external collaborations or technology acquisition (Mansfield, 1988; Veugelers, 1997). Hence, we additionally distinguish whether a) the inputs are directed towards an internal innovation development process (internal input) or b) they are directed at an innovation process that is undertaken in collaboration with outside partners (external input). Fourth, we analyze whether the innovation-performance relationship is moderated by the age of small firms. Different authors suggest that the newness of firms provides unique liabilities and opportunities (Freeman et al., 1983; Bruderl and Schussler, 1990; Henderson, 1999). This analysis enables us to determine whether the absence of routines found in established organizations facilitates or hinders creating and capturing the benefits of innovation (Stinchcombe, 1965; Van de Ven, 1986; Galunic and Rodan, 1998). As a fifth contribution, we consider the cultural context as a moderator of the innovation-performance relationship. Although the management of innovation is a globally important task, the impact of innovation may depend on the national cultural context (e.g., Hofstede, 1980; Hegarty and Hoffman, 1990; Shane, 1995).

Our research specifically focuses on small and medium-sized firms (SMEs) excluding larger organizations. This focus allows us to draw detailed conclusions for this specific context. It thereby specifically addresses questions whether more resource-scarce SME organizations can benefit from innovation. The smallness of the analyzed organization promises that relationships between innovation and performance are more immediate and less confounded by other factors.

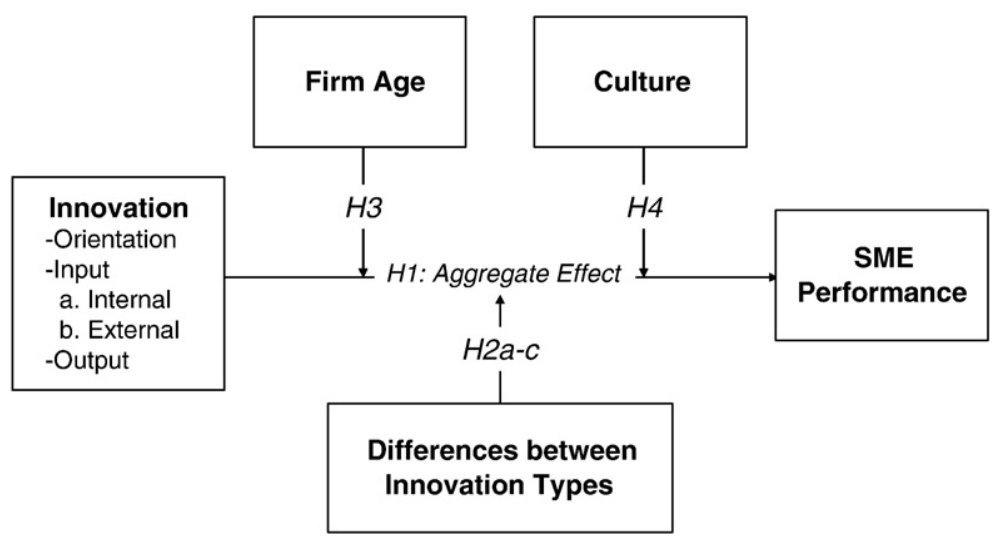

Fig. 1. Model of studied relationships. 


\section{Theoretical background and hypotheses}

\subsection{Innovation and SME performance}

Due to the important role SMEs play for economic and technological development, innovation in the context of smaller firms has received much interest in literature (Acs and Audretsch, 1988). Although SMEs typically face considerable resource constraints, they are often successful innovators. Smaller, nimbler structures and an entrepreneurial posture promoted by founders and managers can facilitate innovation activity in SMEs (Nooteboom, 1994; Vossen, 1998). SMEs pursuing an innovation strategy may benefit in several ways. Schumpeter (1934) argues that innovation is an opportunity for entrepreneurial firms to gain rents through the temporary establishment of a monopoly and considers continuous innovation activity as the key source of longterm entrepreneurial success. Since SMEs are nimbler than their larger counterparts, they can move faster and, hence, obtain these monopoly rents for a longer period of time. The introduction of innovative products, services, processes, or business models tailored to attractive niches is an additional opportunity for SMEs to stand out from competition (Porter, 1980). In so doing, SMEs can benefit from high brand loyalty of buyers and a reduced price sensitivity of demand as a consequence of customers valuing the uniqueness of the innovation (Lieberman and Montgomery, 1988). Serving attractive niches with innovative products is particularly advantageous for SMEs compared to large firms due to their limited size and greater nimbleness. All of these benefits attributable to innovation help SMEs to successfully compete with well-established incumbents that can rely on a much larger resource base than their smaller counterparts. By offering highly innovative products, small firms can avoid price competition. In addition, innovative products may create new demand and, thus, facilitate firm growth. If the innovating SME manages to set high barriers preventing competitors from market entry, the company's position in the industry is strengthened and the innovation can lead to persistent above-average returns (Porter, 1980).

Furthermore, the product development process is considered to be a path-dependent idiosyncratic dynamic capability (Eisenhardt and Martin, 2000; Teece et al., 1997). It leads to competitive advantage via enhancement, recombination or creation of resources and their deployment in value-creating strategies (Grant, 1996; Branzei and Vertinsky, 2006). The ability to reconfigure their resource base due to greater nimbleness and agility is a considerable advantage of SMEs compared to large corporations. As such, from a dynamic capabilities perspective, SMEs can benefit greatly from innovation.

In addition to the direct effects on SMEs' performance, learning during the innovation process (Van De Ven and Polley, 1992) generates absorptive capacity defined as the capability to identify, assimilate, and apply knowledge (Cohen and Levinthal, 1990). The absorptive capacity developed by the innovating SME, in consequence, implies competitive advantages (Zahra and George, 2002). Further benefits of innovation include learning economies, economies of scale and scope, pre-emption of limited resources, advantages in further innovation, and the ability to set standards (Shepherd and Shanley, 1998).

While these theoretical considerations suggest positive effects of innovation, literature also points out a variety of negative effects that can result from innovation. Innovation causes resistances to their adoption in the innovating organization (Ram and Jung, 1991; Hultink and Atuahene-Gima, 2000; Damanpour, 1991) and the market place (Rogers, 2003; Waarts et al., 2002). Moreover, innovation is a risky undertaking which consumes substantial resources (Li and Atuahene-Gima, 2001; Van de Ven, 1986; Eisenhardt and Martin, 2000; Nooteboom, 1994). In addition, the successful development and introduction of innovations demand special organizational resources and capabilities in order to generate and appropriate the benefits of innovation (Schumpeter, 1934; Thornhill, 2006; Branzei and Vertinsky, 2006; Rajesh and Anju, 2009; Junkunc, 2007; Howell et al., 2005). Moreover, the context in which the innovating firm operates might affect the outcome an innovation has for the firm (Shane, 1993; Thornhill, 2006; Dröge et al., 2008; Anokhin and Schulze, 2009). Additionally, innovation is a multifaceted phenomenon (e.g., Kleinknecht et al., 2002; Dewar and Dutton, 1986; Downs and Mohr, 1976; von Hippel, 1990). Hence, it can be suspected that some forms of innovation might be more beneficial than other forms (Damanpour et al., 1989). These considerations suggest that the overall impact of innovation on the performance of a SME is an aggregate effect resulting from both positive and negative mediating effects which are additionally moderated by contextual factors. We expect that based on the aforementioned arguments innovation has a positive aggregate impact on performance, yet that this effect is largely context dependent. Thus, we hypothesize a positive relationship between innovation and SME performance, before addressing moderating factors:

Hypothesis 1. The relationship between innovation and SME performance is positive.

\subsection{Moderators of the innovation-performance relationship}

\subsubsection{Innovation type and performance}

3.2.1.1. Innovation process input vs. innovation process output. The development of an innovation is frequently modeled as a process (e.g., Parthasarthy and Hammond, 2002; Saren, 1984). Following the process understanding, a common distinction relates to factors that are inputs in the innovation process (e.g., financial resources committed to the innovation task or the number of people working in R\&D) and factors that are outputs of the innovations process (number of patents, new services, products, or manufacturing processes) (e.g., Acs and Audretsch, 1988; Brouwer and Kleinknecht, 1999). Firms vary in the amount of inputs they devote to the innovation process. However, the dedication of more inputs to the innovation process does not guarantee innovation outcomes, since the process of developing innovation is complex and characterized by high risks (Wolff, 2007). Thus, the process of the development of innovation needs to be managed diligently in order to increase performance (e.g., Wakasugi and 
Koyata, 1997; Howell et al., 2005). If firms devote substantial resources to the innovation process, but are unable to turn them into innovative offerings, resources are squandered and firm performance suffers. The squandering of resources due to improper innovation process management is especially detrimental for SMEs due to their generally substantial resource constraints. If SMEs devote a significant proportion of their resources to the innovation task, yet, are unable to generate a return on their resource investments, their existence and development can be threatened.

At the same time, other firms might have capabilities to create innovative offerings, production processes or valuable patents without devoting many resources to the innovation task. In so doing, the latter firms are more capable of leveraging their resources which augments firm performance. Based on these arguments associated with the productivity of the innovation process in turning innovation inputs into innovation outputs in SMEs, we expect that SME performance is influenced more strongly by the amount of innovation outcomes than by the amount of innovation inputs. Thus, we posit:

Hypothesis 2a. The positive relationship between innovation process input and performance is weaker than the positive relationship between innovation process output and performance.

3.2.1.2. Innovation orientation vs. innovation process outputs. Innovation is a multi-dimensional phenomenon. Research on innovation has used different concepts to analyze the impact of innovation on performance (e.g., Danneels and Kleinschmidt, 2001; Downs and Mohr, 1976). A basic distinction can be made between the strategic orientation of a firm with respect to innovation (Durand and Coeurderoy, 2001; Edelman et al., 2005; Narver et al., 2004) and the actual process of managing the creation of innovations (DeCarolis, 2003; Deeds, 2001). The strategic orientation of a firm shapes how an organization perceives the environment (Kohli and Jaworski, 1990; Lumpkin and Dess, 1996), sets its goals, allocates resources, structures the valuecreation process (Andrews, 2000; Rajagopalan and Finkelstein, 1992; Siguaw et al., 2006), and builds organizational as well as dynamic capabilities (Eisenhardt and Martin, 2000). As such, the organizational orientation affects strategy formation and strategy implementation by means of shaping the organization (Miller and Friesen, 1978). Entrepreneurial orientation literature suggests that an innovation orientation increases performance especially in situations of resource scarcity, market entry, and when facing established and more resourceful incumbents (Covin and Slevin, 1989; Miller, 1983). Hence, an innovation orientation may be of special relevance to SMEs. Lumpkin and Dess (1996: 142) define innovation orientation as a "... tendency to engage in and support new ideas, novelty, experimentation, and creative processes that may result in new products, services, technological processes." One consequence of an innovation orientation in SMEs can be that resources are dedicated to R\&D and the overarching innovation task which fosters the development of innovative products and services (e.g., Lumpkin and Dess, 1996). Hage (1980) suggests that a combination of a positive attitude of the organization toward change combined with specialist knowledge facilitates the development of radical innovations. Furthermore, an innovation orientation can lead to competence in the technological domain and innovative manufacturing methods (Lumpkin and Dess, 1996). Thus, SMEs with a strong orientation toward innovation are capable to develop specialized, innovative capabilities and innovative offerings. Moreover, an innovation orientation shapes the culture of the SMEs. In organizations that focus on innovations, employees develop a greater sense of commitment and proactivity (Zhou et al., 2005). An innovation orientation can increase employee satisfaction, help in attracting scarce talent, reduce employment turnover, and increase the productivity of the firm. Furthermore, an innovation orientation can have positive branding effects. Additionally, an innovation orientation can foster the development of innovative capabilities of a firm (Branzei and Vertinsky, 2006). Especially for resource-scarce SMEs an orientation towards innovation might be essential to attract and bind various forms of resources such as high-quality employees, recurring revenue from customers, or financial resources from investors which otherwise prefer more established, larger firms. As such, an innovation orientation might be an effective response for SMEs to overcome liabilities associated with smallness. In sum, literature suggests that the benefits of a SME's orientation towards innovation extend beyond tangible outcomes of the innovation process such as patents, new products, services, or production processes. This leads us to propose:

Hypothesis $\mathbf{2 b}$. The positive relationship between an innovation orientation and performance is stronger than the positive relationship between innovation process output and performance.

3.2.1.3. Internal vs. external innovation process input. With respect to innovation, founders and managers of SMEs have to determine how to pursue innovations. Innovation process inputs could be deployed to develop innovations internally or to create innovation in collaboration with external stakeholders. Frequently new and small firms especially in dynamic markets engage in external collaborations to pursue innovations (Zahra and Bogner, 2000; Shan, 1990). However, the literature focusing on the development of innovations through external collaboration proposes both positive and negative implications for SMEs of developing innovations through external collaborations.

Literature stressing the positive effects of developing innovation in conjunction with external, oftentimes larger partners proposes that especially new and small firms rarely have the resources and capabilities to respond to the innovation demands at any given time (Eisenhardt and Schoonhoven, 1996; Jarillo, 1989; Yli-Renko et al., 2001). Hence, the bundling of internal and external resources enables resource-scare SMEs to augment their capacity of delivering innovations to the market (Tyler and Steensma, 1998; Lipparini and Sobrero, 1994). Although benefits of the innovation projects need to be shared, these authors suggest that the likelihood of successful innovation increases and the cash-flow is augmented (Zahra and Bogner, 2000). Especially in dynamic markets, a resourcescarce SME can leverage its unique knowledge by actively configuring and reconfiguring its collaborations. Moreover, external collaborations allow to leverage an external partner's growth (Eisenhardt and Schoonhoven, 1996; Jarillo, 1989; Yli-Renko et al., 2001). 
In contrast, other literature challenges the benefits of developing innovations through external collaborations. The collaboration with external partners in innovation projects implies great complexities with regard to coordination efforts, protection of intellectual property, appropriation of rents, etc. (Roy and Mark, 1991; Kelley et al., 2009; Soh, 2003; Edmondson and Nembhard, 2009). These complexities may overburden the SMEs. Moreover, McGee et al. (1995) find that in order to benefit from external R\&D collaborations, firms need to have experience in the domain. Yet, especially in comparison to their larger counterparts, SMEs might lack the experience needed to manage external collaborations. In comparison, a focus of innovation efforts on internal development reduces complexities, allows the creation of technological expertise, and can speed up the innovation process for the SMEs. Because the innovation process in consequence can be managed more easily, the success-rate might increase.

Moreover, SMEs can be expected to suffer from dominance of external innovation partners. Bigger collaboration partners may dictate the terms in an innovation development project. Since new and small firms generally have few development projects, their dependence on the success of these projects is high. If smaller firms depend on crucial partners in their key development projects, their external network partners might dictate the direction of the development projects, how much resources the SME has to commit, and the terms of how potential benefits are split. As such, the small firms might suffer from a liability of smallness in competitive markets (Porter, 1998). Moreover, new firms might experience a liability of newness lacking experience concerning who to cooperate with and how to manage external collaborations (Stinchcombe, 1965). Furthermore, the benefits of innovation projects do not have to be shared with a potentially stronger partner. From a dynamic perspective, especially new firms might initially obtain unfavorable terms in collaboration projects due to the aforementioned liability of smallness and liability of newness. Focusing on internal development projects allows commercializing the innovation later at more favorable terms. Although the external collaboration can provide benefits, it also implies direct costs and opportunity costs. Due to these problems, SMEs may not be able to generate and appropriate the benefits of innovations in external innovation collaborations. By contrast, a focus on internal innovation development, reduces complexities, allows expertise development, and permits a full appropriation of innovation returns. This leads us to posit:

Hypothesis 2c. Focusing on internal innovation projects has a stronger positive impact on SME performance than focusing on external collaboration in innovation projects.

\subsubsection{Firm age}

The influence of firm age on the innovation-performance relationship in SMEs is a matter of the nature of firms' resources rather than their quantity. While new ventures draw on resources that are less specialized, but flexibly deployable, mature firms have a specialized resource base that enables them to efficiently operate in given market conditions (Amit and Schoemaker, 1993; Thornhill and Amit, 2003). Mature SMEs have established routines, which younger firms lack (Freeman et al., 1983; Bruderl and Schussler, 1990). However, reconfiguring the organizational setting in long-established SMEs can be expected to prove more timedemanding and costly than in new firms which do not have engrained routines (Schreyögg and Kliesch-Eberl, 2007). Firms that remain in current trajectories and do not manage to adapt to environmental change may fail to keep up with competition (DeCarolis, 2003; Sull, 1999). Core competencies based on firm-specific knowledge then become core rigidities (Leonard-Barton, 1992; Van de Ven, 1986). Especially established SMEs might lose their initial competitive advantage of nimbleness as they reinforce core routines, processes, and structures. In contrast, new ventures are free to create processes and structures to form specific, opportunity-related capabilities that are difficult to imitate or substitute, thus, fostering the creation of a competitive advantage. As a result, new entrants that show a high degree of entrepreneurial orientation (Lumpkin and Dess, 1996) often pioneer radical innovations in environments of technologically-induced discontinuities (Christensen and Bower, 1996; Hill and Rothaermel, 2003). Thus, innovation is recognized as a promising strategy for new ventures. Since new firms can be expected to be more flexible and agile than established SMEs, they have a prolonged time of operating under conditions of limited competition in case they pioneer innovations.

Both specialization and flexibility of strategic assets are of importance to the innovation process. There is a trade-off between the specialization of assets and their flexibility when companies mature (Amit and Schoemaker, 1993). Older firms benefit from the specialization of their resources. However, the specialization comes at the cost of more limited flexibility. Van de Ven (1986) highlights that innovation hinges on the ability to adjust as an organization and stresses four obstacles to innovations: 1) people are prone to harvest and protect existing practices and routines that enabled their prior development, 2) while innovations originate often at the individual level, they need to be understood and embraced by the whole organization requiring social impetus, 3) various functional groups need to make a coordinated effort hence resulting in a challenge to link the processes of organization parts to a whole, and 4) the organization needs not only to embrace the innovation but also to transform its existing structure and practices demanding strategic leadership. All these impediments to innovation are certainly greater in an established SME with engraved special routines than in new firms. In sum, pursuing innovation in established firms will be characterized by greater difficulties in comparison to flexible and fast-moving, new firms. Therefore, we argue that new ventures benefit more from innovation than mature SMEs.

Hypothesis 3. The positive relationship between innovation and SME performance is stronger in younger firms than in older firms.

\subsubsection{Culture}

National culture has been related to various aspects of innovation (for a review of studies on cultural influences on innovation see Herbig, 1994 and Jones and Davis, 2000) such as national differences in invention and innovation rates (Shane, 1992; Shane, 1993), cross- 
national product innovation diffusion (Takada and Jain, 1991; Dwyer et al., 2005), R\&D activity (Couto and Vieira, 2004) and R\&D productivity (Kedia et al., 1992), technology alliance formation by entrepreneurs (Steensma et al., 2000), and entrepreneurship (Morris et al., 1993; Tiessen, 1997; Zacharakis et al., 2007). Cultural differences may not only account for cross-national variations in innovation, but may also influence the innovation-performance relationship because cultural differences affect innovation input, the innovation process, and the commercialization of innovations. Out of the four initial cultural dimensions suggested by Hofstede (1980), individualism and power distance have been considered to be most central with respect to innovation management and venture creation processes (Tylecote, 1996; Mitchell et al., 2000). The concepts of individualism and power distance are highly interrelated. In line with Steensma et al. (2000), we focus on one of the two dimensions - individualism.

In accordance with Hofstede (1980), we refer to the individualism-collectivism dimension at the societal level. People in an individualistic culture are motivated by personal goals whereas people in collectivist cultures try to subordinate their personal goals to the goals of a group that they are part of. The level of individualism determines behaviors such as social interactions and psychological needs such as achievement motivation (Hofstede, 1980). These are of high relevance for entrepreneurial and innovation processes (McClelland, 1987). Individualism may influence the relationship between innovation and SME performance for several reasons. Organizational culture is embedded in national culture (Pothokuchi et al., 2002); thus, individualism at the societal level is likely to influence the organizational culture of SMEs. Compared to large enterprises, SMEs are less likely to be influenced by several national cultures because many smaller firms do not have international subsidiaries that could have an additional impact on the culture of the firm. Therefore, the influence of individualism of the home culture can expected to be particularly strong in SMEs.

Individualism at the organizational level can be beneficial, but also detrimental for the success of innovation activities in SMEs. At the invention stage, SMEs can benefit from highly individualistic founders, managers and employees. Individualism fosters creativity, independence, and autonomy (Jones and Davis, 2000) - characteristics that are beneficial for invention processes (Ramamoorthy et al., 2005; Van de Ven, 1986). In addition, individualism has been linked to entrepreneurial orientation (Lee and Peterson, 2000; Mueller and Thomas, 2001) a critical determinant of the success of SMEs (Rauch et al., 2009). Furthermore, individualism can facilitate new product development through product championing (Nakata and Sivakumar, 1996; Howell et al., 2005). Individualism has, therefore, been related to radical innovation activity (Herbig and Miller, 1992).

However, Nakata and Sivakumar (1996) argue that whereas individualism facilitates new product development at the invention stage, it may be detrimental for the implementation of innovation once the initial invention stage is completed and the new product or service needs to be brought to market. In the attempt to successfully commercialize their innovations, employees of firms need to interact with each other as well as with outsiders such as customers, suppliers and other stakeholders (Van de Ven, 1986). Collectivism fosters social interactions and cooperative team behavior (Eby and Dobbins, 1997) and should therefore be beneficial during the commercialization stage. Because SMEs have considerable disadvantages during the commercialization stage, for example regarding distribution channels, marketing resources etc., collectivism is particularly beneficial for such firms. In addition, collectivism can facilitate incremental innovations such as improvements of established products (Herbig and Miller, 1992), because such processes require the communication and collaboration within the firm and the interaction with key suppliers and customers. Individualism might be especially detrimental for SMEs as it can weaken teamwork. Yet, teamwork is needed with regard to the special challenges, resistances, and extra efforts which innovation projects imply (e.g., Lechler, 2001; Ensley et al., 2002; Edmondson and Nembhard, 2009; Hoegl et al., 2003; Dailey, 1978). Because SMEs have a more limited resource base these innovation challenges are augmented. In consequence, SMEs need to rely on teamwork which might be more difficult to accomplish in cultures characterized by high levels of individualism.

Moreover, SMEs in societies characterized by strong collectivism focus in general on imitative strategies and refrain from exhibiting innovative behavior. As fewer SMEs strive for innovation, the competition in markets of innovative products and services is reduced. In consequence, the few SMEs exhibiting innovative behavior can benefit from their innovation activities more than in societies where innovation is pursued by most SMEs.

Overall, the high relevance of teamwork and social interactions for the development and commercialization of innovations as well as market-related benefits of being an innovator in an environment of less innovation, leads us to propose that collectivism strengthens the innovation-performance relationship for SMEs.

Hypothesis 4. Individualism moderates the link between innovation and SME performance such that the positive relationship is stronger in countries with a low level of individualism.

\section{Method}

\subsection{Study identification process}

In order to identify relevant studies, we primarily conducted computerized keyword searches in the databases Business Source Elite, EconLit, ISI Web of Knowledge, and ABI Inform. In addition, we manually searched in the most important journals in management (e.g., Academy of Management Journal), strategy (e.g., Strategic Management Journal), innovation management (e.g., Journal of Product Innovation Management), and entrepreneurship (e.g., Journal of Business Venturing, Entrepreneurship Theory and Practice) as well as conference proceedings (e.g., Frontiers of Entrepreneurship Research). As a third step, we searched the reference sections of relevant articles for further studies. 
Because the selection of studies has an impact on the research outcomes of meta-analyses, it is important to specify inclusion criteria (Hunter and Schmidt, 2004). We developed the following catalogue of inclusion criteria:

(1) Studies needed to address the innovation-performance relationship in SMEs as a major research question. There is no common definition of a SME (e.g., OECD, 2002). Typically, employment data is used as a criterion, but the cut-off point varies across countries. Most frequently, the upper limit is 250 employees as in the European Union or 500 employees as in the U.S. (OECD, 2002). Because most empirical research in the area has been carried out in the U.S., we define SMEs as firms with less than 500 employees.

(2) The performance variable refers to the company as a whole, not to single products or product lines in order to ensure that the studies focus on the same level of analysis. The performance measure can be return-, growth- or market-based as well as subject to respondents' ratings on return-, growth- or market-based performance indicators.

(3) As there is no commonly used construct measuring innovation, we consider different innovation measures, including innovation orientation indicators (e.g., innovation strategy), internal innovation input indicators (e.g., R\&D intensity), external innovation input indicators (e.g., R\&D alliances), and output indicators (e.g., number of new products) (e.g., Brouwer and Kleinknecht, 1999).

A number of studies did not report the necessary statistics: specifically, Pearson's product-moment correlations $r$ or values that can be converted into $r$. One study was removed because it used a simulation instead of a field study approach (Marinova, 2004). The final sample consists of $k=42$ independent samples analyzing more than 21,000 firms $(N=21,270)$ which represent a strong empirical base for a meta-analysis (Brinckmann et al., 2010; Read et al., 2009).

Table 1 gives an overview about the included empirical studies. The 42 independent samples stem from 46 published and unpublished studies. If several studies used the same sample of firms (DeCarolis and Deeds, 1999; Deeds and Decarolis, 1997; Deeds et al., 1998; Deeds, 2001 and Li, 2001; Li and Atuahene-Gima, 2001, 2002), we included the sample only once in the calculations in order to avoid biases caused by an overrepresentation of specific samples. In the two cases where articles based on the same sample reported different effect sizes because they linked different innovation measures to different performance measures, we calculated average effect sizes and included each sample only once based on average effect sizes.

For 18 samples, effect sizes were reported for more than one innovation measure class. 24 studies analyzed performance effects of only one innovation measure. 19 out of 42 samples focus on firms in North America, 13 samples include firms from Europe, 6 include Asian firms, and one study examines Australian companies. With respect to firm age, the samples were divided into two groups: 14 samples focused on younger companies, whereas 12 represented established companies. Sample sizes range from 40 (Wang and Bee Lian, 2004) to 2999 (Kemp et al., 2003). Effect sizes vary from $r=-.33$ (McGee et al., 1995) to $r=.76$ (Guo et al., 2005). The large variance in effect sizes may be attributed to different sample sizes, but may also be caused by variations in contextual factors. The method of meta-analysis can give profound information on average effects as well as moderating influences of contextual variables.

\subsection{Coding and operationalization of variables}

\subsubsection{Dependent variables}

Although the explanation of performance differentials between companies is a core issue in strategic management and entrepreneurship research, there is no consensus as to how the performance construct should be assessed in empirical research. On the contrary, researchers use a wide variety of different measures, usually without justification (Brush and Vanderwerf, 1992; Murphy et al., 1996). Following insights from a meta-analytic review of relationships between performance measures, we focused on studies that measure performance along three dimensions: accounting returns, growth, and stock market performance (Combs et al., 2005). Therefore, we included studies that used return/profit-based (e.g., return on assets (ROA), return on sales (ROS), growth-oriented (e.g., sales growth, market share growth), and stock market-based measures of financial performance (e.g., Tobin's $Q$ market-to-book value). Furthermore, we included empirical work that relies on subjective measures based on the three dimensions described above. There is evidence that self-reported measures highly correlate with objective measures of performance (Dess and Robinson, 1984). Return-based, growth-based, and subjective performance based assessments are equally used across studies. Stock market-based performance measures are underrepresented which is a result of the focus on SMEs.

\subsubsection{Independent and moderator variables}

Similar to the measurement of performance, there are a number of ways to assess innovation. Along the innovation process and in line with innovation literature we classify innovation measures into input-related and output-related indicators (e.g., Brouwer and Kleinknecht, 1999; Acs and Audretsch, 1988). Additionally, we include measures on innovation orientation. Because input in the innovation process can stem from internal and external sources, we divided input measures into two sub-categories: internal innovation process input (e.g., R\&D expenditures, R\&D experience) and external innovation process input (e.g. R\&D collaboration, external technological sourcing). Input and output measures are equally located across studies.

The definition of a new venture varies across studies. Depending on the industry setting, it can take between 8 and 12 years until companies mature (Covin et al., 1990; Zahra, 1996). Within the scope of this meta-analysis, we use an average age of 12 years as a cut-off point between young and mature firms. 
Table 1

Overview of studies.

\begin{tabular}{|c|c|c|c|c|c|c|}
\hline Authors, year & Journal & $\begin{array}{l}\text { Sample } \\
\text { size }\end{array}$ & Effect size & $\begin{array}{l}\text { Innovation measure } \\
\text { classification }\end{array}$ & $\begin{array}{l}\text { Age } \\
\text { classification }\end{array}$ & $\begin{array}{l}\text { Country } \\
\text { (individualism category) }\end{array}$ \\
\hline Akgün et al. (2007) & J Eng Tech Manag & 163 & 0.56 & Strategic orientation & & Turkey (low) \\
\hline Arndt and Sternberg (2000) & Eur Plann Stud & 1300 & 0.05 & External input & Established & Europe \\
\hline Birley and Westhead (1990) & Strategic Manage J & 249 & 0.04 & Output & Established & UK (high) \\
\hline Chandler and Hanks (1994) & J Bus Venturing & 155 & $\begin{array}{r}0.22 \\
-0.03\end{array}$ & $\begin{array}{l}\text { Internal input } \\
\text { Strategic orientation }\end{array}$ & New & US (high) \\
\hline Dai and Liu (2009) & Int Bus Rev & 711 & $\begin{array}{l}0.25 \\
0.23\end{array}$ & $\begin{array}{l}\text { Internal input } \\
\text { Output }\end{array}$ & New & China (low) \\
\hline DeCarolis and Deeds (1999) & Strategic Manage J, & 90 & 0.30 & Internal input & New & US (high) \\
\hline Deeds and Decarolis (1997) & J Bus Venturing, & & 0.27 & External input & & \\
\hline Deeds et al. (1998) & Entrep Theory Pract, & & 0.23 & Output & & \\
\hline Deeds (2001) & J Eng Tech Manag & & & & & \\
\hline Dowling and McGee (1994) & Manage Sci & 52 & $\begin{array}{r}0.49 \\
-0.06\end{array}$ & $\begin{array}{l}\text { Internal input } \\
\text { External input }\end{array}$ & New & US (high) \\
\hline Durand and Coeurderoy (2001) & J Bus Venturing & 582 & 0.18 & Strategic orientation & Established & France (medium) \\
\hline Edelman et al. (2005) & J Bus Venturing & 192 & -0.07 & Strategic orientation & & US (high) \\
\hline Eddleston et al. (2008) & J Manage Studies & 74 & 0.27 & Strategic orientation & & US (high) \\
\hline Garcia-Morales et al. (2007) & Technovation & 242 & 0.50 & Strategic orientation & & Spain (low) \\
\hline Gibbons and O'Connor (2003) & $J$ Enterprising Cult & 336 & 0.36 & Strategic orientation & & Ireland (medium) \\
\hline Gopalakrishnan (2000) & J High Tech Manag Res & 101 & 0.21 & Output & & US (high) \\
\hline Guo et al. (2005) & J Account Audit Finance & 122 & $\begin{array}{l}0.76 \\
0.19\end{array}$ & $\begin{array}{l}\text { Internal input } \\
\text { Output }\end{array}$ & & US (high) \\
\hline Han and Celly (2008) & Canadian J Admin Sci & 70 & 0.31 & Strategic orientation & New & Canada (high) \\
\hline Heeley et al. (2007) & Acad Manage J & 1413 & $\begin{array}{l}0.04 \\
0.07\end{array}$ & $\begin{array}{l}\text { Internal input } \\
\text { Output }\end{array}$ & Established & US (high) \\
\hline Heunks (1998) & Small Bus. Econ. & 200 & 0.02 & Output & Established & Europe \\
\hline Kalafsky and MacPherson (2002) & Small Bus. Econ. & 104 & $\begin{array}{l}0.31 \\
0.23\end{array}$ & $\begin{array}{l}\text { Internal input } \\
\text { Output }\end{array}$ & Established & US (high) \\
\hline Kemp et al. (2003) & Working Paper & 2999 & $\begin{array}{l}0.07 \\
0.18\end{array}$ & $\begin{array}{l}\text { Internal input } \\
\text { Output }\end{array}$ & & The Netherlands (high) \\
\hline Kishida (2005) & Unpublished Dissertation & 319 & $\begin{array}{l}0.13 \\
0.20 \\
0.10\end{array}$ & $\begin{array}{l}\text { External input } \\
\text { Strategic orientation } \\
\text { Output }\end{array}$ & New & US (high) \\
\hline Kreiser et al. (2000) & Front Entrep Res & 1671 & 0.10 & Strategic orientation & & Several \\
\hline Lee et al. (2001) & Strategic Manage J & 137 & $\begin{array}{l}0.11 \\
0.45\end{array}$ & $\begin{array}{l}\text { External input } \\
\text { Output }\end{array}$ & New & Korea (low) \\
\hline Lee and Habte-Giorgis (2004) & Int Bus Rev & 455 & 0.19 & Internal input & & US (high) \\
\hline Sandvik and Sandvik (2003) & Int J Res Mark & 298 & 0.07 & Output & & Norway (medium) \\
\hline Li and Atuahene-Gima (2001) & Acad Manage J, & 184 & 0.18 & External input & New & China (low) \\
\hline $\begin{array}{l}\mathrm{Li} \text { and Atuahene-Gima (2002) } \\
\mathrm{Li}(2001)\end{array}$ & $\begin{array}{l}\text { Strategic Manage J } \\
\text { J High Tech Manag Res }\end{array}$ & & 0.44 & Strategic orientation & & \\
\hline Lin et al. (2008) & Int J Manpower & 333 & 0.28 & Strategic orientation & New & Taiwan (low) \\
\hline Lööf and Heshmati (2006) & Econ Innovat New Tech & 838 & $\begin{array}{l}0.19 \\
0.35\end{array}$ & $\begin{array}{l}\text { Internal input } \\
\text { Output }\end{array}$ & & Sweden (medium) \\
\hline Lööf and Heshmati (2006) & Econ Innovat New Tech & 314 & $\begin{array}{l}0.16 \\
0.17\end{array}$ & $\begin{array}{l}\text { Internal input } \\
\text { Output }\end{array}$ & & Sweden (medium) \\
\hline Love et al. (2009) & Int J Ind Org & 1536 & 0.05 & Output & Established & Ireland / UK \\
\hline Mavondo et al. (2005) & Eur J Marketing & 227 & 0.05 & Strategic orientation & & Australia (high) \\
\hline McGee et al. (1995) & Strategic Manage J & 210 & $\begin{array}{r}0.07 \\
-0.33\end{array}$ & $\begin{array}{l}\text { Internal input } \\
\text { External input }\end{array}$ & New & US (high) \\
\hline Nas and Leppälahti (1997) & Working Paper & 283 & 0.06 & Internal input & & Norway (medium) \\
\hline Qian and $\mathrm{Li}$ (2003) & Strategic Manage J & 67 & 0.25 & Internal input & New & \\
\hline Richard et al. (2004) & Acad Manage J & 153 & 0.08 & Output & Established & US (high) \\
\hline Thornhill (2006) & J Bus Venturing & 845 & -0.02 & Output & Established & Canada (high) \\
\hline Thornhill and Amit (1998) & Front Entrep Res & 2962 & 0.21 & Output & New & Canada (high) \\
\hline Vermeulen et al. (2003) & Working Paper & 651 & $\begin{array}{l}-0.25 \\
-0.21 \\
-0.06\end{array}$ & $\begin{array}{l}\text { Internal input } \\
\text { External input } \\
\text { Output }\end{array}$ & & The Netherlands (high) \\
\hline Wang and Bee Lian (2004) & J Small Bus Manage & 40 & $\begin{array}{l}0.38 \\
0.31\end{array}$ & $\begin{array}{l}\text { Internal input } \\
\text { Strategic orientation }\end{array}$ & New & Singapore (low) \\
\hline Wolff and Pett (2006) & J Small Bus Manage & 182 & $\begin{array}{l}0.39 \\
0.22\end{array}$ & $\begin{array}{l}\text { Internal input } \\
\text { Strategic orientation }\end{array}$ & Established & US (high) \\
\hline Yalcinkaya et al. (2007) & J Int Marketing & 111 & 0.15 & Output & Established & US (high) \\
\hline Zahra and Bogner (2000) & J Bus Venturing & 116 & $\begin{array}{l}0.28 \\
0.28 \\
0.18\end{array}$ & $\begin{array}{l}\text { Internal input } \\
\text { External input } \\
\text { Output }\end{array}$ & New & US (high) \\
\hline Zhou et al. (2009) & J Bus Research & 184 & 0.23 & Strategic orientation & Established & Several \\
\hline
\end{tabular}


To address cultural influences on the innovation-performance relationship in SMEs we applied Hofstede's individualism dimension (Hofstede, 1980). For the bivariate analysis it is necessary to create groups of countries with similar cultural values. Due to the overrepresentation of U.S. firms in our sample, a median split was not practical for individualism. We, thus, decided to distinguish three groups characterized by low, medium, and high individualism. Individualism is high in Anglo-Saxon countries and low in Asian countries included in this sample. Most European countries in the sample show medium levels of individualism.

\subsubsection{Control variable}

As a control variable, we coded whether the innovation was measured objectively (1) or subjectively (0). In their seminal work, Downs and Mohr (1976) introduced the distinction between primary and secondary attributes of innovations. Primary attributes such as cost or communicability of innovation are innately connected to the innovation and invariant across organizations and observations. Since they are inherently associated with innovation, they can be confidently observed. In contrast, secondary attributes are subjective assessments of the innovation based on individual or organization cognition and dependent on the assessor's characteristics and circumstances. The distinction between objective and subjective measurements of innovation enables us to determine if there is a substantive difference between individual assessments of innovation and their intrinsic characteristics which has important implications for the derived findings and future research designs (Tornatzky and Klein, 1982).

\subsection{Meta-analytical procedure}

Empirical research on the innovation-performance relationship is characterized by a large number of small sample size field studies that show highly controversial findings. Such empirical work is usually limited in generalizability due to restrictions in underlying assumptions as they focus on populations which fulfill certain criteria (e.g., industry, size, and age). Meta-analysis is a method to integrate such results across previously conducted independent studies (Glass, 1976). By virtue of increased statistical power, it enables researchers to provide profound estimates of the true relation (Zhao et al., 2004). In comparison to narrative reviews, meta-analysis is less biased as it systematically quantifies the relationship between variables (Hunter and Schmidt, 2004).

Meta-analysis allows for a systematic quantification of the relationship between innovation and organizational performance while accounting for statistical artifacts. For our bivariate analysis, we use the procedures suggested by Hunter and Schmidt (2004) which are most commonly applied in strategic management research (e.g., Dalton et al., 1998; Daniel et al., 2004). Sampling error is a major source of artifactual variance in study results. In order to account for this problem, we weight effect sizes by the sample size of the respective study before aggregating them into an overall effect size $r$. The homogeneity of populations and the significance of effect sizes are crucial questions in meta-analysis. We calculate credibility and confidence intervals to give information on homogeneity of populations and significance of effect sizes. The 95\% confidence interval shows whether the relationship between the variables significantly varies from zero (Finkelstein et al., 1995). A confidence interval that does not include zero indicates a significant relationship between variables. In contrast to confidence intervals, credibility intervals do not refer to the likelihood of error in the estimation but to the distribution of parameter values (Hunter and Schmidt, 2004). A 95\% credibility interval that includes zero indicates a heterogeneous population and, thus, potential moderating effects (Hunter and Schmidt, 2004). For analyzing moderator effects derived from theory, the sample is divided into sub-samples. For each subsample, we calculate average sample-size weighted effect sizes. To test differences in the effect sizes between sub-samples, we calculate $z$ values. Further, a variable is considered to be a moderator if the average residual variance of the sub-samples is lower than the residual variance in the original data set (Hunter et al., 1982).

There are some critical issues concerning the meta-analytical procedure described above. First, many studies reported more than one effect size because they use different operationalizations of the dependent or the independent variable. Including all of these effect sizes would violate the independence assumption. Thus, we calculate averages across the effect sizes reported in each study. This is a common procedure, even though it does not consider intercorrelations among variables (Cheung and Chan, 2004). A second problem refers to outliers. Whenever weighted averages are used, outliers can have a strong influence on the mean effect size as well as variance estimates (Hunter and Schmidt, 2004). In our sample, there is one observation ( $r=.76$ for the correlation between internal innovation input and firm performance) which could be considered to be an outlier (Guo et al., 2005). However, an analysis without this observation did not significantly change our results. Therefore, we report results based on the complete sample. Third, the meta-analytical procedure may have a significant influence on research results (Bausch et al., 2008). We address this issue by applying two techniques which show the robustness of our findings. While meta-analyses in entrepreneurship commonly apply bivariate analysis techniques (e.g., Rauch et al., 2009; Schwenk and Shrader, 1993; Song et al., 2008), recently the use of multivariate analysis in entrepreneurship research has been advocated to substantiate the findings (Brinckmann et al., 2010). Following this literature, we applied meta-regressions using procedures suggested by Lipsey and Wilson (2001). Metaregressions use moderating variables as independent variables to predict the inverse coefficient adjusted effect sizes of the individual studies. As such, meta-regressions are an innovative method to test for moderating effects that go beyond bivariate analyses. Meta-regressions allow for simultaneously scrutinizing the significance and effect strength of different moderators. In analogy to regressions, the independent variables are expected to impact the dependent variable which is the effect strength between innovation and performance found in the individual studies. Control variables in meta-regressions serve the same purpose as control variables in other regressions; they are used to control for effects that these variables have on the dependent variable. 


\section{Results}

Tables 2 and 3 depict the bivariate and meta-regression results, respectively. The results of the analyses are consistent. According to the bivariate analysis, innovation is positively linked to SME performance at the aggregate level $(r=.133)$. A confidence interval not including zero indicates that this effect significantly differs from zero. Although Hypothesis 1 is supported, it needs to be highlighted that the credibility interval includes zero which suggests that this effect depends on contextual factors that moderate the innovation-performance relationship.

Moderator analyses were performed for type of activity in the innovation process, firm age, and individualism. A major part of this study is concerned with the innovation process and its implications for firm performance. The results suggest that innovation orientation $(r=.196)$ has a higher impact on performance than innovation input $(r=.099)$ and innovation output $(r=.143)$. However, the differences between output and input $(p=0.120)$ as well as output and orientation $(p=.114)$ are not significant.

Additionally, we performed meta-regressions. Multivariate regression analyses offer the opportunity to account for interdependencies between variables that go unobserved in bivariate analyses. In our meta-regressions, innovation output serves as the reference category because Hypotheses $2 \mathrm{a}$ and $2 \mathrm{~b}$ compare innovation input and innovation orientation to innovation output. Hence, coefficients for innovation input and innovation orientation refer to the difference in effect sizes compared to innovation output. The meta-regression shows a significant negative coefficient for innovation process input compared to innovative output. Thus, we find support for Hypothesis 2a. The regression analyses further demonstrate that innovation orientation has a significantly stronger impact on performance than innovation output. This result provides support for Hypothesis $2 \mathrm{~b}$.

Within the innovation input dimension, we further distinguished between internal and external input to the innovation process. With respect to this distinction, we find that firms benefit from internally derived investments in innovation activity $(r=.107)$, whereas external input $(r=.001)$ has no effect on SME performance. The difference between the effect sizes is significant. The meta-regression differentiating between internal and external input to the innovation process confirms this result. It shows that the performance impact of external input to the innovation process is significantly lower than that of the reference category. Meanwhile, the performance impact of internal innovation input is as strong as innovation output. This indicates further support for Hypothesis 2c. Although our hypotheses concerning differences between innovation process variables are largely supported by both analyses, it needs to be mentioned that all credibility intervals within subgroups include zero. It is, therefore, likely that further moderators of the relationship between innovation and SME performance exist.

Results of both methods of analyses demonstrate that firm age affects the innovation-performance relationship negatively. The correlation between innovation and firm performance is significantly higher in new ventures $(r=.206)$ than in mature firms $(r=.069)$. A significantly negative coefficient for firm age in the meta-regression confirms the results found in the bivariate analysis. Hence, the data strongly support Hypothesis 3. Furthermore, the credibility interval for the sub-sample of new ventures suggests that this sub-sample is a homogeneous population. However, the 75\%-rule proposed by Hunter and Schmidt (2004) is not fulfilled. That means a relatively high percentage of the observed variance in the sub-group of new ventures cannot be attributed to sampling error. Thus, other moderators may exist.

Table 2

Bivariate meta-analytical results.

\begin{tabular}{|c|c|c|c|c|c|c|c|c|c|}
\hline \multirow[b]{2}{*}{ H1: Overall relationship } & \multirow{2}{*}{$\frac{k}{42}$} & \multirow{2}{*}{$\frac{N}{21,270}$} & \multirow{2}{*}{$\frac{r}{0.1331}$} & \multicolumn{2}{|c|}{ Confidence interval } & \multicolumn{2}{|c|}{ Credibility interval } & \multirow[t]{2}{*}{$Z$} & \multirow[t]{2}{*}{$p$} \\
\hline & & & & 0.0963 & 0.1699 & -0.0898 & 0.3560 & & \\
\hline \multicolumn{10}{|l|}{ H2: Process } \\
\hline Strategic orientation & 16 & 4954 & 0.1960 & 0.1232 & 0.2687 & -0.0745 & 0.4664 & $2.0222^{a}$ & 0.0216 \\
\hline Input & 22 & 10,741 & 0.0991 & 0.0399 & 0.1584 & -0.1646 & 0.3629 & $1.1728^{b}$ & 0.1204 \\
\hline a. Internal & 18 & 8801 & 0.1071 & 0.0357 & 0.1785 & -0.1830 & 0.3971 & $1.6146^{c}$ & 0.0532 \\
\hline b. External & 9 & 3058 & 0.0005 & -0.1073 & 0.1084 & -0.3050 & 0.3060 & & \\
\hline Output & 21 & 14,268 & 0.1434 & 0.0991 & 0.1878 & -0.0459 & 0.3328 & $1.2083^{d}$ & 0.1135 \\
\hline \multicolumn{10}{|l|}{ H3: Age } \\
\hline New ventures & 14 & 5445 & 0.2059 & 0.1646 & 0.2472 & 0.0843 & 0.3274 & 4.6600 & 0.0000 \\
\hline Mature firms & 12 & 6859 & 0.0685 & 0.0280 & 0.1089 & -0.0454 & 0.1823 & & \\
\hline \multicolumn{10}{|l|}{ H4: Individualism } \\
\hline High & 23 & 11,851 & 0.1145 & 0.0671 & 0.1620 & -0.0965 & 0.3256 & $-4.3089^{\mathrm{e}}$ & 0.0000 \\
\hline Medium & 6 & 2651 & 0.2045 & 0.1279 & 0.2811 & 0.0396 & 0.3694 & $-1.9576^{f}$ & 0.0251 \\
\hline Low & 7 & 1810 & 0.3220 & 0.2404 & 0.4035 & 0.1360 & 0.5079 & $-2.0576^{\mathrm{g}}$ & 0.0199 \\
\hline
\end{tabular}

a Orientation vs. Input.

b Output vs. Input.

c Internal vs. External input.

d Orientation vs. Output.

e High vs. Low.

f High vs. Medium.

g Medium vs. Low. 
Table 3

Results of meta-regression.

\begin{tabular}{|c|c|c|c|c|}
\hline \multirow[t]{2}{*}{ Independent variables } & \multicolumn{2}{|c|}{ Input combined } & \multicolumn{2}{|c|}{ Internal/external } \\
\hline & $B$ & $p$ & $B$ & $p$ \\
\hline Constant & 0.766 & 0.000 & 0.677 & 0.000 \\
\hline Objective innovation measurement & -0.195 & 0.000 & -0.172 & 0.000 \\
\hline Strategic orientation & 0.191 & 0.000 & 0.192 & 0.000 \\
\hline Input & -0.095 & 0.000 & & \\
\hline Internal input & & & 0.020 & 0.368 \\
\hline External input & & & -0.081 & 0.009 \\
\hline Age & -0.147 & 0.000 & -0.150 & 0.000 \\
\hline Individualism & -0.002 & 0.001 & -0.002 & 0.000 \\
\hline$R$ square & 0.738 & & 0.711 & \\
\hline Adjusted $R$ square & 0.645 & & 0.578 & \\
\hline$F$-value & 7.903 & & 5.335 & \\
\hline Significance-level & 0.001 & & 0.006 & \\
\hline
\end{tabular}

With regard to the cultural context, we had proposed that individualism has a negative effect on the innovation-performance relationship. This hypothesis is strongly supported. Although innovation is a performance-enhancing strategy in all three groups of countries represented in our sample, we observe relatively high differences in effect sizes between groups. Firms based in countries with low individualism benefit more from innovation $(r=.322)$ than firms operating in countries with medium $(r=.205)$ and high levels of individualism $(r=.115)$. All differences relating to cultural moderator variables are significant. The meta-regression as a multivariate analysis technique underlines the robustness of our findings. It is noteworthy that we again find indicators for the homogeneity of two sub-groups. The credibility interval for the sub-samples of firms in countries with medium and high levels of individualism does not include zero. Yet, as in the case of new ventures, less than $75 \%$ of the observed variance in effect sizes is attributable to sampling error.

In the meta-regression we controlled for subjective vs. objective measurements of innovation. This control variable shows a significant moderating effect on the relationship between innovation and SME performance. In additional post-hoc analyses, we further studied whether the innovation-performance relationship is dependent on the performance measure used. The bivariate analysis revealed no significant differences between profitability, growth, and stock market performance measures. A further robustness check based on meta-regression was not feasible due to high collinearity caused by performance and innovation-type dummies.

\section{Discussion}

This study aggregated empirical evidence regarding the innovation-performance relationship in SMEs. It was directed to uncover whether smaller, resource-scarce firms benefit from pursuing innovation. The findings show that both an innovation orientation and innovation activities create value for new and established SMEs. Although innovation can imply high initial and continuous investments, risks, and uncertainty, the benefits such as differentiation from competition, customer loyalty, price premiums for innovative products, and entry barriers for potential imitators generally seem to outweigh the costs. By and large, SMEs that pursue an innovation strategy appear to have sufficient resources and capabilities to benefit from innovation.

However, this work also uncovers different factors that influence the strength of the relationship between innovation and SME performance. Comparing the strength of the impact of innovation orientation on firm performance with the impact of innovation process outcomes (e.g., patents, new products or services) on performance, we find that SMEs benefit significantly more from a strategic innovation orientation than from just focusing on developing innovative products. Although the bivariate analysis shows that strengths of both relationships are comparable, the multivariate analysis indicates a significant difference. This finding suggests that only focusing on delivering innovative offerings to the market place might not fully leverage the potential of innovation. SMEs can benefit even more if they develop, communicate, and embrace an innovation orientation. An organizational orientation towards innovation can lead to the development of more ambitious goals, the allocation of resources in areas where they create more value, an inspiring and challenging firm culture, organizational proactivity, as well as effective risk analysis and risk-taking. Beyond these internally directed benefits, SMEs which focus on innovation can benefit from a positive perception by market participants leading to higher brand equity, obtaining better collaboration partners, and attracting highly skilled employees. Our findings suggest that these positive internal and external effects go beyond the positive effects innovative offerings have for SMEs.

The strong positive effects of an innovation orientation on success can lead entrepreneurs and small business executives to conclude that by focusing more attention on innovation and devoting more resources to the innovation tasks, the benefits of innovation will substantiate automatically. Our findings, however, caution that this is a dangerous assumption. The comparison of benefits of innovation process inputs vs. outputs indicates that SMEs benefit more from creating innovation outputs than generally dedicating more resources to the innovation task. This finding has important implications for innovation researchers and practitioners. It underlines the call for a better understanding as to how innovation inputs can effectively be turned into marketable outputs. There appears to be a substantial difference between dedicating more resources to innovation and achieving innovative offerings. In order to reap the benefits of innovation, resources need to be dedicated to the innovation task, but the conversion into innovative offerings also needs to be managed diligently. 
When pursuing an innovation strategy, entrepreneurs and small business owners face the quandary of deciding whether they should pursue the innovation development projects as firm-internal projects or with external partners. Prior research predominantly advocates the focus on external collaborations and networking for new and small ventures. Yet, our findings exhibit that internal innovation projects lead to greater firm performance than innovation projects with external partners. Moreover, our meta-analytical results show that the innovation projects that focus on external collaboration do not increase the performance of SMEs. Meanwhile, the internal development of innovations increases significantly the performance of SMEs. This surprising evidence indicates that external, innovation-focused collaborations can have substantial disadvantages for SMEs. Innovation projects which tend to be complex and risky endeavors can be complicated substantially when dealing with external partners which, in consequence, can prolong the duration of the innovation project and imply greater transaction costs in form of greater coordination, supervision, or intellectual property protection efforts (Williamson, 1979). The findings can also be explained by the competitive dynamics literature, suggesting that smaller market participants can be dominated by larger incumbents (Porter, 2004). Resource-scarce, smaller entities may receive unfavorable terms in the joint innovation projects. Following our findings, entrepreneurs and small business owners are advised to consider developing the innovation internally. This might reduce the administrative necessities, could speed up the innovation project, might enable the building of innovation capabilities and might allow a full appropriation of the returns from the innovation projects for the SMEs. From a theoretical perspective this finding provides indication that when dealing with external innovation partners, SMEs might indeed suffer from a liability of newness and smallness. To address the liability of newness and smallness, entrepreneurs and SME managers are advised to determine the degree of external collaboration dynamically. Initially, as collaboration terms are unfavorable, they could focus on internal innovation development. As they gain better insights and market recognition, the focus can shift towards engaging more actively in external collaborations at more attractive terms. A limitation of this study is certainly that we cannot distinguish between different types of external innovation collaborations. Whether external collaboration yield benefits for the SMEs, may largely depend on the kind of external partners the SMEs collaborate with. For example, disruptive innovations might easier to develop internally, while incremental innovations might be better pursued in external collaborations (Christensen and Raynor, 2003). Moreover, collaborations with smaller external partners might be more beneficial for SMEs as competitive dynamics are more favorable and a liability of smallness might be less detrimental. Additionally, depending on the type of collaboration partner, different performance effects may result (Belderbos et al., 2004).

Empirical evidence provided in this study suggests that new ventures benefit more from innovation than mature SMEs. Considering the trade-off between flexibility and specialization of resources as companies mature (Amit and Schoemaker, 1993), the flexibility of new firms might be more beneficial for innovation-success than specialization of assets found in established firms. As such, the flexibility of new firms might enable them to adapt to changing environments or induce rapid industry changes themselves. This finding is especially insightful as it highlights that the often cited liability of newness of new ventures (Stinchcombe, 1965) can proof to be an asset for the development of new organizations if entrepreneurs choose adequate strategies.

Furthermore, our findings contradict the common-place assumption that countries characterized by individualism, such as the U.S., provide more fertile grounds for innovation. This meta-analysis of innovation research shows that innovating SMEs in cultures with high levels of individualism benefit significantly less from innovations than firms in more collective cultures. In fact, the innovation-performance relationship is lowest for companies based in highly individualistic countries such as the U.S. while the greatest positive impact of innovation on performance is found in Asian countries. A high level of individualism may constrain teamwork as well as internal and external social interactions. Yet, social interactions are important for the success of innovation projects (Nakata and Sivakumar, 1996). Moreover, in more collectivist countries, innovation might be a less popular endeavor. If fewer firms compete in the innovation terrain, the firms that decide to pursue innovations might find more fertile grounds. The firms pursuing innovation in collectivist countries might encounter less competition for scarce innovation resources (e.g., engineers, facilities, and innovation networks), less competition in the initial niche innovation markets, and longer lead times. Hence, entrepreneurs and executives in SMEs in collectivist countries might be well-advised to consider pursuing innovations to enhance their firm performance.

A few potential limitations of this study have to be addressed. This meta-analysis attempted to avoid a publication bias by including non-published findings. Yet, access to such empirical work is limited. However, we do not expect that there is a strong normative bias of reviewers and editors with regard to publishing non-significant or negative relationships between innovation and performance. Another limitation is the survival bias included in the primary studies. If individual studies generally suffer from survival bias (innovation may lead to failure - yet the failure of these firms is not documented in the studies), our aggregated findings also suffer from this bias. A third limitation relates to the sample of the studies included. We analyzed SMEs which are a popular focus of management and entrepreneurship researchers. While already more homogenous than studies including large firms, still a substantial variance in firms sizes can be observed. In order to identify the consequence of resource scarcity more clearly, the sampled studies could have been reduced to small firm studies. However, in this regard we believe that the new firm sub-sample analysis provides indications of the special effects of resource scarcity. New firms tend to be very small entities (e.g., Shane, 2008). Since the impact of innovation on performance in new firms was substantially more positive than in more established SMEs, it appears that resource limitations do not hinder firms from harvesting the benefits of innovation.

Our study provides some directions for future research. An important performance gap was identified between innovation inputs and innovation outputs. Hence, more research is needed to explain how resources dedicated to innovation are squandered and how SMEs should manage the innovation process. Moreover, while we presented various theoretical explanations as to why new firms benefit more from innovation than established ones, the specific relationships of how innovation enables strong firm 
performance for new ventures are opaque. Future research should dedicate more efforts into unearthing the mechanisms of how new firms achieve the benefits of innovation. A better understanding of these mechanisms may help in building entrepreneurship theory. Furthermore, we know little about how long firms have to be able to absorb innovation costs before innovation actually pays off. An improved understanding of the time dimension can facilitate theory refinement regarding the innovation performance relationship as well as enlighten managers in new and more established small firms about how to effectively approach the promising area of innovation.

Overall, this study identified a number of important contextual factors that impact the innovation performance relationship. In so doing, we hope to foster a more contextual understanding of the entrepreneurship phenomena. We believe that the identified variables are indicators of a variety of salient contextual dimensions; yet, we do not want to suggest that the identified variables are the only ones. More research can be directed at uncovering other moderators and illustrating specific mechanisms how innovation affects firm success.

\section{Acknowledgements}

We would like to thank Professor Simon Parker and two anonymous JBV reviewers for constructive comments on earlier versions of the paper. This research was supported by a research grant by the Volkswagen Foundation (II/82 408).

\section{References}

Acs, Z.J., Audretsch, D.B., 1988. Innovation in large and small firms: an empirical analysis. American Economic Review 78 (4), 678-690.

Akgün, A.E., Keskin, H., Byrne, J.C., Aren, S., 2007. Emotional and learning capability and their impact on product innovativeness and firm performance. Technovation 27 (9), 501-513.

Amit, R., Schoemaker, P.J.H., 1993. Strategic assets and organizational rent. Strategic Management Journal 14 (1), $33-46$.

Andrews, A.O., 2000. The people/performance balance in IPO firms: the effect of the chief executive officer's financial orientation. Entrepreneurship - Theory and Practice 25 (1), 93-106.

Anokhin, S., Schulze, W.S., 2009. Entrepreneurship, innovation, and corruption. Journal of Business Venturing 24 (5), $465-476$.

Arndt, O., Sternberg, R., 2000. Do manufacturing firms profit from intraregional innovation linkages? An empirical based answer. European Planning Studies 8 (4), 465-485.

Bausch, A., Pils, F., Wilhelm, A., 2008. Meta-analysis in strategic management research: on evidence-based management. Hunter/Schmidt, and Hedges/Olkin, Strategic Management Society Annual International Conference. Cologne, Germany.

Belderbos, R., Carree, M., Lokshin, B., 2004. Cooperative R\&D and firm performance. Research Policy 33 (10), 1477-1492.

Berggren, E., Nacher, T., 2001. Introducing new products can be hazardous to your company: use the right new-solutions delivery tools. Academy of Management Executive 15 (3), 92-101.

Birley, S., Westhead, P., 1990. Growth and performance contrasts between 'types' of small firms. Strategic Management Journal 11 (7), $535-557$.

Block, Z., MacMillan, I., 1993. Corporate Venturing. Harvard Business Press, Cambridge, MA.

Branzei, O., Vertinsky, I., 2006. Strategic pathways to product innovation capabilities in SMEs. Journal of Business Venturing 21 (1), $75-105$.

Brinckmann, J., Grichnik, D., Kapsa, D., 2010. Should entrepreneurs plan or just storm the castle? A meta-analysis on contextual factors impacting the business planning-performance relationship in small firms. Journal of Business Venturing 25 (1), 24-40.

Brouwer, E., Kleinknecht, A., 1999. Innovative output, and a firm's propensity to patent. An exploration of CIS micro data. Research Policy 28 (6), 615-624.

Bruderl, J., Schussler, R., 1990. Organizational mortality: the liabilities of newness and adolescence. Administrative Science Quarterly 35 (3), $530-547$.

Brush, C.G., Vanderwerf, P.A., 1992. A comparison of methods and sources for obtaining estimates of new venture performance. Journal of Business Venturing 7 (2), 157-170.

Camison-Zornosa, C., Lapiedra-Alcami, R., Segarra-Ciprés, M., Boronat-Navarro, M., 2004. A meta-analysis of innovation and organizational size. Organization Studies 25 (3), 331-361.

Chandler, G.N., Hanks, S.H., 1994. Market attractiveness, resource-based capabilities, venture strategies, and venture performance. Journal of Business Venturing 9 (4), 331-349.

Cheung, S.F., Chan, D.K.S., 2004. Dependent effect sizes in meta-analysis: incorporating the degree of interdependence. Journal of Applied Psychology 89 (5), 780-791.

Christensen, C.M., Bower, J.L., 1996. Customer power, strategic investment, and the failure of leading firms. Strategic Management Journal 17 (3), $197-218$.

Christensen, C.M., Raynor, M.E., 2003. The Innovator's Solutions: Creating and Sustaining Successful Growth. Harvard Business School Publishing, Boston, MA.

Cohen, W.M., Levinthal, D.A., 1990. Absorptive capacity: a new perspective on learning and innovation. Administrative Science Quarterly 35 (1), $128-152$.

Combs, J.G., Crook, T.R., Shook, C., 2005. The dimensionality of organizational performance and its implications for strategic management research. In: Ketchen, D., Bergh, D. (Eds.), Research Methodology in Strategy and Management: 259-286. Elsevier, San Diego, CA.

Couto, J.P., Vieira, J.C., 2004. National culture and research and development activities. Multinational Business Review 12 (1), $19-35$.

Covin, J.G., Slevin, D.P., 1989. Strategic management of small firms in hostile and benign environments. Strategic Management Journal 10 (1), $75-87$.

Covin, J.G., Slevin, D.P., Covin, T.J., 1990. Content and performance of growth-seeking strategies: a comparison of small firms in high-and low-technology industries. Journal of Business Venturing 5 (6), 391-402.

Crawford, C.M., 1987. New product failure rates - facts and fallacies. Research Management 22 (5), 9-13.

Dai, O., Liu, X., 2009. Returnee entrepreneurs and firm performance in Chinese high-technology industries. International Business Review 18 (4), $373-386$.

Dailey, R.C., 1978. The role of team and task characteristics in R\&D team collaborative problem solving and productivity. Management Science 24 (15), $1579-1588$.

Dalton, D.R., Daily, C.M., Ellstrand, A.E., Johnson, J.L., 1998. Meta-analytic reviews of board composition, leadership structure, and financial performance. Strategic Management Journal 19 (3), 269-290.

Damanpour, F., 1991. Organizational innovation: a meta-analysis of effects of determinants and moderators. Academy of Management Journal 34 (3), 555-590.

Damanpour, F., Szabat, K.A., Evan, W.M., 1989. The relationship between types of innovation and organizational performance. Journal of Management Studies 26 (6), 587-602.

Daniel, F., Lohrke, F.T., Fornaciari, C.J., Turner Jr., R.A., 2004. Slack resources and firm performance: a meta-analysis. Journal of Business Research 57 (6), $565-574$.

Danneels, E., 2002. The dynamics of product innovation and firm competences. Strategic Management Journal 23 (12), $1095-1121$.

Danneels, E., Kleinschmidt, E., 2001. Product innovativeness from the firm's perspective: its dimensions and their relation with project selection and performance. Journal of Product Innovation Management 18 (6), 357-373.

Davidsson, P., 2004. Researching Entrepreneurship. Springer, Boston, MA.

DeCarolis, D.M., 2003. Competencies and imitability in the pharmaceutical industry: an analysis of their relationship with firm performance. Journal of Management 29, 27-50.

DeCarolis, D.M., Deeds, D.L., 1999. The impact of stocks and flows of organizational knowledge on firm performance: an empirical investigation of the biotechnology industry. Strategic Management Journal 20 (10), 953-968.

Deeds, D.L., 2001. The role of R\&D intensity, technical development and absorptive capacity in creating entrepreneurial wealth in high technology start-ups. Journal of Engineering and Technology Management 18 (1), 29-47. 
Deeds, D.L., Decarolis, D., 1997. The impact of firm-specific capabilities on the amount of capital raised in an initial public. Journal of Business Venturing 12 (1), 31-46.

Deeds, D.L., DeCarolis, D., Coombs, J.E., 1998. Firm-specific resources and wealth creation in high-technology ventures: evidence from newly public biotechnology firms. Entrepreneurship: Theory \& Practice 22 (3), 55-73.

Dess, G.G., Robinson Jr., R.B., 1984. Measuring organizational performance in the absence of objective measures: the case of the privately-held firm and conglomerate business unit. Strategic Management Journal 5 (3), 265-273.

Dess, G.G., Lumpkin, G.T., Covin, J.G., 1997. Entrepreneurial strategy making and firm performance: tests of contingency and configurational models. Strategic Management Journal 18 (9), 677-695.

Dewar, R.D., Dutton, J.E., 1986. The adoption of radical and incremental innovations: an empirical analysis. Management Science 32 (11), $1422-1433$.

Dowling, M.J., McGee, J.E., 1994. Business and technology strategies and new venture performance: a study of the telecommunications equipment industry. Management Science 40 (12), 1663-1667.

Downs Jr., G.W., Mohr, L.B., 1976. Conceptual issues in the study of innovation. Administrative Science Quarterly 21 (4), $700-714$

Dröge, C., Roger, C., Nukhet, H., 2008. New product success: is it really controllable by managers in highly turbulent environments? Journal of Product Innovation Management 25 (3), 272-286.

Durand, R., Coeurderoy, R., 2001. Age, order of entry, strategic orientation, and organizational performance. Journal of Business Venturing 16 (5), $471-494$.

Dwyer, S., Mesak, H., Hsu, M., 2005. An exploratory examination of the influence of national culture on cross-national product diffusion. Journal of International Marketing 13 (2), 1-27.

Eby, L.T., Dobbins, G.H., 1997. Collectivistic orientation in teams: an individual and group-level analysis. Journal of Organizational Behavior 18 (3), 275-295.

Eddleston, K.A., Kellermanns, F.W., Sarathy, R., 2008. Resource configuration in family firms: linking resources, strategic planning and technological opportunities to performance. Journal of Management Studies 45 (1), 26-50.

Edelman, L.F., Brush, C.G., Manolova, T., 2005. Co-alignment in the resource-performance relationship: strategy as mediator. Journal of Business Venturing 20 (3), 359-383.

Edmondson, A.C., Nembhard, I.M., 2009. Product development and learning in project teams: the challenges are the benefits. Journal of Product Innovation Management 26 (2), 123-138.

Eisenhardt, K.M., Martin, J.A., 2000. Dynamic capabilities: what are they? Strategic Management Journal 21 (10/11), 1105-1121.

Eisenhardt, K.M., Schoonhoven, C.B., 1996. Resource-based view of strategic alliance formation: strategic and social effects in entrepreneurial firms. Organization Science 7 (2), 136-150.

Ensley, M.D., Pearson, A.W., Amason, A.C., 2002. Understanding the dynamics of new venture top management teams: cohesion, conflict, and new venture performance. Journal of Business Venturing 17 (4), 365-386.

Finkelstein, L.M., Burke, M.J., Raju, N.S., 1995. Age discrimination in simulated employment contexts: an integrative analysis. Journal of Applied Psychology 80 (6), 652-663.

Freeman, J., Carroll, G.R., Hannan, M.T., 1983. The liability of newness: age dependence in organizational death rates. American Sociological Review 48 (5), $692-710$.

Galunic, D.C., Rodan, S., 1998. Resource recombinations in the firm: knowledge structures and the potential for Schumpeterian innovation. Strategic Management Journal 19 (12), 1193-1201.

Garcia-Morales, V.J., Lloréns-Montes, F.J., Verdú-Jover, A.J., 2007. Influence of personal mastery on organizational performance through organizational learning and innovation in large firms and SMEs. Technovation 27 (9), 547-568.

Gibbons, P.T., O'Connor, T., 2003. Strategic posture, technology strategy and performance among small firms. Journal of Enterprising Culture 11 (2), $131-146$.

Glass, G., 1976. Primary, secondary and meta-analysis of research. Educational Research 5, 3-8.

Gopalakrishnan, S., 2000. Unraveling the links between dimensions of innovation and organizational performance. Journal of High Technology Management Research 11 (1), 137-153.

Grant, R.M., 1996. Toward a knowledge-based theory of the firm. Strategic Management Journal 17, 109-122 (Winter Special Issue).

Guo, R.-J., Baruch, L., Zhou, N., 2005. The valuation of biotech IPOs. Journal of Accounting, Auditing \& Finance 20 (4), 423-459.

Hage, J., 1980. Theories of organizations: form, process, and transformation. John Wiley \& Sons, New York, NY.

Han, M., Celly, N., 2008. Strategic ambidexterity and performance in international new ventures. Canadian Journal of Administrative Sciences 25 (4), 335-349.

Heeley, M.B., Matusik, S.F., Jain, N., 2007. Innovation, appropiability, and the underpricing of initial public offerings. Academy of Management Journal 50 (1), 209-225.

Hegarty, W.H., Hoffman, R.C., 1990. Product/market innovations: a study of top management involvement among four cultures. Journal of Product Innovation Management 7 (3), 186-199.

Henderson, A.D., 1999. Firm strategy and age dependence: a contingent view of the liabilities of newness, adolescence, and obsolescence. Administrative Science Quarterly 44 (2), 281-314.

Herbig, P., 1994. The Innovation Matrix: Culture and Structure, Prerequisites to Innovation. Quorum Books.

Herbig, P.A., Miller, J.C., 1992. Culture and technology: does the traffic move in both directions. Journal of Global Marketing 6 (3), 75-104.

Heunks, F.J., 1998. Innovation, creativity and success. Small Business Economics 10 (3), 263-272.

Hill, C.W.L., Rothaermel, F.T., 2003. The performance of incumbent firms in the face of radical technological innovation. Academy of Management Review 28 (2), 257-274.

Hoegl, M., Parboteeah, K.P., Gemuenden, H.G., 2003. When teamwork really matters: task innovativeness as a moderator of the teamwork-performance relationship in software development projects. Journal of Engineering and Technology Management 20, $281-302$.

Hofstede, G., 1980. Culture's Consequences: International Differences in Work-related Values. Sage, Newbury Park, CA.

Howell, J.M., Shea, C.M., Higgins, C.A., 2005. Champions of product innovations: defining, developing, and validating a measure of champion behavior. Journal of Business Venturing 20 (5), 641-661.

Hultink, E.J., Atuahene-Gima, K., 2000. The effect of sales force adoption on new product selling performance. Journal of Product Innovation Management 17 (6), 435-450.

Hunter, J.E., Schmidt, F.L., 2004. Methods of meta-analysis: correcting error and bias in research findings. Sage Publications, Thousand Oaks, CA.

Hunter, J.E., Schmidt, F.L., Jackson, G.B., 1982. Meta-analysis: cumulating research findings across studies. Sage, Beverly Hills, CA.

Jarillo, J.C., 1989. Entrepreneurship and growth: the strategic use of external resources. Journal of Business Venturing 4 (2), $133-147$.

Jones, G.K., Davis, H.J., 2000. National culture and innovation: implications for locating global R\&D operations. Management International Review (MIR) 40 (1), 11-39.

Junkunc, M.T., 2007. Managing radical innovation: the importance of specialized knowledge in the biotech revolution. Journal of Business Venturing 22 (3), $388-411$.

Kalafsky, R.V., MacPherson, A.D., 2002. The competitive characteristics of U.S. manufacturers in the machine tool industry. Small Business Economics 19 (4), 355-369.

Kedia, B.L., Keller, R.T., Julian, S.D., 1992. Dimensions of national culture and the productivity of R\&D units. Journal of High Technology Management Research 3, $1-18$.

Kelley, D.J., Peters, L., O'Connor, G.C., 2009. Intra-organizational networking for innovation-based corporate entrepreneurship. Journal of Business Venturing 24 (3), 221-235.

Kemp, R.G.M., Folkeringa, M., de Jong, J.P.J., Wubben, E.F.M., 2003. Innovation and Firm Performance. SCALES, Zoetemer.

Kim, W.C., Maubourgne, R., 2005. Blue ocean strategy. Harvard Business School Press, Boston, MA.

Kishida, R., 2005. An Analysis of New Venture Performance: Linking Product Innovation and Legitimation. Case Western Reserve University.

Kleinknecht, A., Van Montfort, K., Brouwer, E., 2002. The non-trivial choice between innovation indicators. Economics of Innovation \& New Technology 11 (2), 109-121. 
Knight, F., 1921. Risk, Uncertainty and Profit. Houghton-Mifflin, New York, NY.

Kohli, A.K., Jaworski, B.J., 1990. Market orientation: the construct, research propositions, and managerial implications. Journal of Marketing 54, 1-18 April.

Kreiser, P., Marino, L., Weaver, K.M., 2000. Assessing the relationship between entrepreneurial orientation, the external environment, and firm performance. Frontiers of Entrepreneurship Research.

Lechler, T., 2001. Social interaction: a determinant of entrepreneurial team venture success. Small Business Economics 16 (4), $263-278$.

Lee, S.M., Peterson, S.J., 2000. Culture, entrepreneurial orientation, and global competitiveness. Journal of World Business 35 (4), 401-416.

Lee, R.P., Chen, Q., 2009. The immediate impact of new product introductions on stock price: the role of firm resources and size. Journal of Product Innovation Management 26 (1), 97-107.

Lee, J., Habte-Giorgis, B., 2004. Empirical approach to the sequential relationships between firm strategy, export activity, and performance in U.S. manufacturing firms. International Business Review 13 (1), 101-129.

Lee, C., Lee, K., Pennings, J.M., 2001. Internal capabilities, external networks, and performance: a study on technology-based ventures. Strategic Management Journal 22 (6-7), 615-640.

Leonard-Barton, D., 1992. Core capabilities and core rigidities: a paradox in managing new product development. Strategic Management Journal 13, 111-125.

Li, H., 2001. How does new venture strategy matter in the environment-performance relationship? Journal of High Technology Management Research 12 (2), $183-204$.

Li, H., Atuahene-Gima, K., 2001. Product innovation strategy and the performance of new technology ventures in China. Academy of Management Journal 44 (6), $1123-1134$

Li, H., Atuahene-Gima, K., 2002. The adoption of agency business activity, product innovation, and performance in Chinese technology ventures. Strategic Management Journal 23 (6), 469-490.

Lieberman, M., Montgomery, D., 1988. First-mover advantages. Strategic Management Journal 9, 41-58.

Lin, C.-H., Peng, C.-H., Kao, D.T., 2008. The innovativeness effect of market orientation and learning orientation on business performance. International Journal of Manpower 29 (8), 752-772.

Lipparini, A., Sobrero, M., 1994. The glue and the pieces: entrepreneurship and innovation in small-firm networks. Journal of Business Venturing 9 (2), $125-140$.

Lipsey, M.W., Wilson, D.B., 2001. Practical Meta-analysis. Sage Publications, Thousand Oaks, CA.

Lööf, H., Heshmati, A., 2006. On the relationship between innovation and performance: a sensitivity analysis. Economics of Innovation \& New Technology 15 (4/5), 317-344.

Love, J.H., Roper, S., Du, J., 2009. Innovation, ownership and profitability. International Journal of Industrial Organization 27 (3), $424-434$.

Lumpkin, G.T., Dess, G.G., 1996. Clarifying the entrepreneurial orientation construct and linking it to performance. Academy of Management Review 21 (1), $135-172$.

Majchrzak, A., Cooper, L.P., Neece, O.E., 2004. Knowledge reuse for innovation. Management Science 50 (2), 174-188.

Mansfield, E., 1988. The speed and cost of industrial innovation in Japan and the United States: external vs. internal technology. Management Science 34 (10), $1157-1168$.

Marinova, D., 2004. Actualizing innovation effort: the impact of market knowledge diffusion in a dynamic system of competition. Journal of Marketing 68 (3), 1-20.

Mavondo, F.T., Chimhanzi, J., Stewart, J., 2005. Learning orientation and market orientation: relationship with innovation, human resource practices and performance. European Journal of Marketing 39 (11/12), 1235-1263.

McClelland, D.C., 1987. Characteristics of successful entrepreneurs. Journal of Creative Behavior 21 (3), 219-233.

McGee, J.E., Dowling, M.J., Megginson, W.L., 1995. Cooperative strategy and new venture performance: the role of business strategy and management experience. Strategic Management Journal 16 (7), 565-580.

Miller, D., 1983. The correlates of entrepreneurship in three types of firms. Management Science 29 (7), 770-791.

Miller, D., Friesen, P.H., 1978. Archetypes of strategy formulation. Management Science 24 (9), 921-933.

Mitchell, R.K., Smith, B., Seawright, K.W., Morse, E.A., 2000. Cross-cultural cognitions and the venture creation decision. Academy of Management Journal 43 (5), 974-993.

Morris, M.H., Avila, R.A., Allen, J., 1993. Individualism and the modern corporation: implications for innovation and entrepreneurship. Journal of Management 19 (3), 595-612.

Mueller, S.L., Thomas, A.S., 2001. Culture and entrepreneurial potential: a nine country study of locus of control and innovativeness. Journal of Business Venturing 16 (1), 51-75.

Murphy, G.B., Trailer, J.W., Hill, R.C., 1996. Measuring performance in entrepreneurship research. Journal of Business Research 36 (1), 15-23.

Nakata, C., Sivakumar, K., 1996. National culture and new product development: an integrative review. Journal of Marketing 60 (1), 61-72.

Narver, J.C., Slater, S.F., MacLachlan, D.L, 2004. Responsive and proactive market orientation and new-product success. Journal of Product Innovation Management 21 (5), 334-347.

Nas, S.O., Leppälahti, A., 1997. Innovation, Firm Profitability and Growth. Oslo.

Nohria, N., Gulati, R., 1996. Is slack good or bad for innovation? Academy of Management Journal 39 (5), 1245-1264.

Nooteboom, B., 1994. Innovation and diffusion in small firms: theory and evidence. Small Business Economics 6 (5), 327-347.

OECD, 2002. OECD Small and Medium Enterprise Outlook. OECD Publishing, Paris.

Parthasarthy, R., Hammond, J., 2002. Product innovation input and outcome: moderating effects of the innovation process. Journal of Engineering \& Technology Management 19 (1), 75-91.

Porter, M.E., 1980. Competitive Strategy: Techniques for Analyzing Industries and Competitors. Free Press, New York.

Porter, M.E., 1998. Competitive Strategy: Techniques for Analyzing Industries and Competitors. Free Press, New York, NY.

Porter, M.E., 2004. Competitive Advantage. Free Press, New York.

Pothokuchi, V., Damanpour, F., Choi, J., Chen, C., Park, S., 2002. National and organizational culture differences and international joint venture performance. Journal of International Business Studies 33, 243-265.

Qian, G., Li, L., 2003. Profitability of small- and medium-sized enterprises in high-tech industries: the case of the biotechnology industry. Strategic Management Journal 24 (9), 881-887.

Rajagopalan, N., Finkelstein, S., 1992. Effects of strategic orientation and environmental change on senior management reward systems. Strategic Management Journal 13 (S1), 127-141.

Rajesh, S., Anju, S., 2009. Can quality-oriented firms develop innovative new products? Journal of Product Innovation Management 26 (2), $206-221$.

Ram, S., Jung, H.S., 1991. "Forced" adoption of innovations in organizations: consequences and implications. Journal of Product Innovation Management 8 (2), 117-126.

Ramamoorthy, N., Flood, P.C., Slattery, T., Sardessai, R., 2005. Determinants of innovative work behaviour: development and test of an integrated model. Creativity \& Innovation Management 14 (2), 142-150.

Rauch, A., Frese, M., 2006. Meta-analyses as a tool for developing entrepreneurship research and theory. Advances in Entrepreneurship, Innovation and Economic Growth 9, 29-51.

Rauch, A., Wiklund, J., Lumpkin, G.T., Frese, M., 2009. Entrepreneurial orientation and business performance: An assessment of past research and suggestions for the future. Entrepreneurship: Theory \& Practice 33 (3), 761-787.

Read, S., Song, M., Smit, W., 2009. A meta-analytic review of effectuation and venture performance. Journal of Business Venturing 24 (6), $573-587$.

Richard, O.C., Barnett, T., Dwyer, S., Chadwick, K., 2004. Cultural diversity in management, firm performance and the moderating role of entrepreneurial orientation dimensions. Academy of Management Journal 47 (2), 255-266.

Roberts, E.B., 1990. Evolving toward product and market-orientation: the early years of technology-based firms. Journal of Product Innovation Management 7 (4), $274-287$.

Rogers, E.A., 2003. The Diffusion of Innovations. Free Press, New York.

Rousseau, D.M., Manning, J., Denyer, D., 2008. Evidence in management and organizational science: assembling the field's full weight of scientific knowledge through syntheses. Academy of Management Annals 2, 475-515. 
Roy, R., Mark, D., 1991. External linkages and innovation in small and medium-sized enterprises. R\&D Management 21 (2), $125-138$.

Sandvik, I.L., Sandvik, K., 2003. The impact of market orientation on product innovativeness and business performance. International Journal of Research in Marketing 20 (4), 355-376.

Saren, M.A., 1984. A classification and review of models of the intra-firm innovation process. R\&D Management 14 (1), 11-24.

Schreyögg, G., Kliesch-Eberl, M., 2007. How dynamic can organizational capabilities be? Towards a dual-process model of capability dynamization. Strategic Management Journal 28 (9), 913-933.

Schumpeter, A., 1934. The Theory of Economic Development. Harvard University Press, Cambridge, MA.

Schumpeter, J.A., 1982. The Theory of Economic Development: an Inquiry into Profits, Capital, Credit, Interest, and the Business Cycle. Transaction Publishers, Piscataway, NJ.

Schwenk, C.B., Shrader, C.B., 1993. Effects of formal strategic planning on financial performance in small firms: a meta-analysis. Entrepreneurship - Theory and Practice 17 (3), 53-64.

Shan, W., 1990. An empirical analysis of organizational strategies by entrepreneurial high-technology firms. Strategic Management Journal 11, 129-139.

Shane, S., 1992. Why do some societies invent more than others? Journal of Business Venturing 7, 29-46.

Shane, S., 1993. Cultural influences on national rates of innovation. Journal of Business Venturing 8 (1), 59-73.

Shane, S., 1995. Uncertainty avoidance and the preference for innovation championing roles. Journal of International Business Studies 26 (1), 47-68.

Shane, S., 2008. The Illusions of Entrepreneurship: the Costly Myths That Entrepreneurs, Investors, and Policy Makers Live By. Yale University Press, New Haven.

Shepherd, D.A., Shanley, M., 1998. New Venture Strategy: Timing, Environmental Uncertainty and Performance. Sage, London.

Siguaw, J.A., Simpson, P.M., Enz, C.A., 2006. Conceptualizing innovation orientation: a framework for study and integration of innovation research. Journal of Product Innovation Management 23 (6), 556-574.

Soh, P.-H., 2003. The role of networking alliances in information acquisition and its implications for new product performance. Journal of Business Venturing 18 (6), 727-744.

Song, M., Podoynitsyna, K., van der Bij, H., Halman, J.I.M., 2008. Success factors in new ventures: a meta-analysis. Journal of Product Innovation Management 25 (1), 7-27.

Steensma, H.K., Marino, L., Weaver, K.M., Dickson, P.H., 2000. The influence of national culture on the formation of technology alliances by entrepreneurial firms. Academy of Management Journal 43 (5), 951-973.

Stinchcombe, A.L., 1965. Social structure and organizations. In: March, J.G. (Ed.), Handbook of organizations: 142-193. Rand McNally, Chicago.

Sull, D., 1999. Why good companies go bad? Harvard Business Review 77 (4), 42-56.

Takada, H., Jain, D., 1991. Cross-national analysis of diffusion of consumer durable goods in Pacific Rim countries. Journal of Marketing 55 (2), $48-54$.

Teece, D.J., Pisano, G., Shuen, A., 1997. Dynamic capabilities and strategic management. Strategic Management Journal 18 (7), $509-533$.

Thornhill, S., 2006. Knowledge, innovation and firm performance in high- and low-technology regimes. Journal of Business Venturing 21 (5), 687-703.

Thornhill, S., Amit, R., 1998. Growth management of emergent firms in Canada. In: Reynolds, P.D. (Ed.), Frontiers of Entrepreneurship Research. Babson College, Wellesley, MA.

Thornhill, S., Amit, R., 2003. Learning about failure: bankruptcy, firm age, and the resource-based view. Organization Science 14 (5), $497-509$.

Tiessen, J.H., 1997. Individualism, collectivism, and entrepreneurship: a framework for international comparative research. Journal of Business Venturing 12 (5), 367-384.

Tornatzky, L.G., Klein, K.J., 1982. Innovation characteristics and innovation adoption-implementation: a meta-analysis of findings. IEEE Transactions on Engineering Management 29 (1), 28-43.

Tylecote, A., 1996. Cultural differences affecting technological innovation in Western Europe. European Journal of Work \& Organizational Psychology 5 (1), $137-174$.

Tyler, B.B., Steensma, H.K., 1998. The effects of executives' experiences and perceptions on their assessment of potential technological alliances. Strategic Management Journal 19 (10), 939-965.

Van de Ven, A.H., 1986. Central problems in the management of innovation. Management Science 32 (5), $590-607$.

Van De Ven, A.H., Polley, D., 1992. Learning while innovating. Organization Science 3 (1), 92-116.

Vermeulen, P.A.M., O'Shaughnessy, K.C., De Jong, J.P.J., 2003. Innovation in SMEs: an Empirical Investigation of the Input-Throughput-Output-Performance Model. EIM, Zoetermeer.

Vermeulen, P.A.M., De Jong, J.P.J., O'Shaughnessy, 2005. Identifying key determinants for new product introductions and firm performance in small service firms. Service Industry Journal 25 (5), 625-640.

Veugelers, R., 1997. Internal R \& D expenditures and external technology sourcing. Research Policy 26 (3), $303-315$.

von Hippel, E., 1990. Task partitioning: an innovation process variable. Research Policy 19, 407-418.

Vossen, R.W., 1998. Relative strengths and weaknesses of small firms in innovation. International Small Business Journal 16 (3), 88-94.

Waarts, E., van Everdingen, Y.M., van Hillegersberg, J., 2002. The dynamics of factors affecting the adoption of innovations. Journal of Product Innovation Management 19 (6), 412-423.

Wakasugi, R., Koyata, F., 1997. R\&D, firm size and innovation outputs: are Japanese firms efficient in product development? Journal of Product Innovation Management 14 (5), 383-392.

Wang, C.K., Bee Lian, A., 2004. Determinants of venture performance in Singapore. Journal of Small Business Management 42 (4), $347-363$.

Williamson, O.E., 1979. Transaction-cost economics: the governance of contractual relations. Journal of Law and Economics 22 (2), $233-261$.

Wolff, M.F., 2007. Forget R\&D spending - think innovation. Research Technology Management 50 (2), 7-9.

Wolff, J.A., Pett, T.L., 2006. Small-firm performance: modeling the role of product and process improvements. Journal of Small Business Management 44 (2), $268-284$.

Yalcinkaya, G., Calantone, R.J., Griffith, D.A., 2007. An examination of exploration and exploitation capabilities: implications for product innovation and market performance. Journal of International Marketing 15 (4), 63-93.

Yli-Renko, H., Autio, E., Sapienza, H.J., 2001. Social capital, knowledge acquisition, and knowledge exploitation in young technology-based firms. Strategic Management Journal 22 (6/7), 587-613.

Zacharakis, A.L., McMullen, J.S., Shepherd, D.A., 2007. Venture capitalists' decision policies across three countries: an institutional theory perspective. International Business Studies 38 (5), 691-709.

Zahra, S., 1996. Technology strategy and new venture performance: a study of corporate-sponsored and independent. Journal of Business Venturing 11 (4), 289-321.

Zahra, S.A., Bogner, W.C., 2000. Technology strategy and software new ventures' performance: exploring the moderating effect of the competitive environment. Journal of Business Venturing 15 (2), 135-173.

Zahra, S.A., George, G., 2002. Absorptive capacity: a review, reconceptualization, and extension. Academy of Management Review 27 (2), $185-203$.

Zhao, H., Luo, Y., Suh, T., 2004. Transaction cost determinants and ownership-based entry mode choice: a meta-analytical review. Journal of International Business Studies 35 (6), 524-544.

Zhou, K.Z., Gao, G.Y., Yang, Z., Zhou, N., 2005. Developing strategic orientation in China: antecedents and consequences of market and innovation orientations. Journal of Business Research 58 (8), 1049-1058.

Zhou, K.Z., Brown, J.R., Dev, C.S., 2009. Market orientation, competitive advantage, and performance: a demand-based perspective. Journal of Business Research 62 (11), 1063-1070. 